\title{
Disappearance and appearance of an indigestible marker in feces from growing pigs as affected by previous- and current- diet composition
}

\author{
Brandy M. Jacobs ${ }^{1}$, John F. Patience ${ }^{1}$, Merlin D. Lindemann ${ }^{2}$, Kenneth J. Stalder ${ }^{1}$ and Brian J. Kerr ${ }^{3^{*}}$
}

\begin{abstract}
Background: Indigestible markers are commonly utilized in digestion studies, but the complete disappearance or maximum appearance of a marker in feces can be affected by diet composition, feed intake, or an animal's BW. The objectives of this study were to determine the impact of previous (Phase 1, P1) and current- (Phase 2, P2) diet composition on marker disappearance $(\mathrm{Cr})$ and appearance ( $\mathrm{Ti}$ ) in pigs fed 3 diets differing in NDF content.

Results: When pigs were maintained on the $25.1,72.5$, and $125.0 \mathrm{~g} / \mathrm{kg}$ NDF diets, it took $5.1,4.1$, and $2.5 \mathrm{~d}$, respectively, for $\mathrm{Cr}$ levels to decrease below the limit of quantitation; or 4.6, 3.7, or $2.8 \mathrm{~d}$, respectively, for Ti to be maximized. These effects were not, however, independent of the previous diet as indicated by the interaction between P1 and P2 diets on fecal marker concentrations $(P<0.01)$. When dietary NDF increased from $\mathrm{P} 1$ to $\mathrm{P} 2$, it took less time for fecal $\mathrm{Cr}$ to decrease or fecal Ti to be maximized (an average of $2.5 \mathrm{~d}$ ), than if NDF decreased from P1 to P2 where it took longer for fecal $\mathrm{Cr}$ to decrease or fecal Ti to be maximized (an average of $3.4 \mathrm{~d}$ ).

Conclusions: Because of the wide range in excretion times reported in the literature and improved laboratory methods for elemental detection, the data suggests that caution must be taken in considering dietary fiber concentrations of the past and currently fed diets so that no previous dietary marker addition remains in the digestive tract or feces such that a small amount of maker is present to confound subsequent experimental results, and that marker concentration have stabilized when these samples are collected.
\end{abstract}

Keywords: Adaptation, Digestibility, Fiber, Indigestible marker, Pig

\section{Background}

Indigestible markers are commonly used in animal nutrition studies to calculate digestibility coefficients, with chromic oxide, titanium dioxide, and acid insoluble ash being the most common in swine research [1]. Physiological aspects associated with gastric emptying or rate of passage are complex and affected by a variety of factors $[2,3]$. Rate of passage can be affected by BW [4], feed intake level [5], dietary fiber type and level [6-8], particle size [9], and genetics [10]. In addition, rates of passage in the gastrointestinal tract are not consistent,

\footnotetext{
* Correspondence: brian.kerr@ars.usda.gov

${ }^{3}$ USDA-ARS-National Laboratory for Agricultural and the Environment, Ames 50010, IA, USA

Full list of author information is available at the end of the article
}

being pulsatile over time $[11,12]$. The appearance of the first marker peak is relatively consistent at the terminal ileum of pigs, occurring approximately $6 \mathrm{~h}$ following a meal, dropping to minimum levels $24 \mathrm{~h}$ post-meal [13]. In contrast, digesta flow through the hind gut is longer and more variable, where mean transit times through the entire digestive tract have been reported to be less than $50 \mathrm{~h}$ [7] to over $100 \mathrm{~h} \mathrm{[6].} \mathrm{Imbeath} \mathrm{et} \mathrm{al.} \mathrm{[13]} \mathrm{re-}$ ported that $4 \mathrm{~d}$ was needed before marker concentrations were near zero after marker withdrawal, while others $[14,15]$ have reported that their appearance in the feces is stabilized 4 to $5 \mathrm{~d}$ after feeding.

Currently, there is no standard time for pigs to be adapted to a diet, a specific number of days an animal should be sampled, or the number of days between 
collection periods in swine research utilizing inert markers. As a consequence, the objectives of this study were to: 1) determine the impact of previous (P1) and currently-fed (P2) diet composition on the complete disappearance P2 marker $(\mathrm{Cr})$ and 2) determine the impact of previous and currently-fed diet composition on the complete appearance of P2 marker (Ti) in growing pigs fed diets differing in fiber content.

\section{Methods}

The experiment was conducted under protocols approved by the University of Kentucky Institutional Animal Care and Use Committee.

\section{Feeding management}

Diets (Table 1) were formulated to contain varying levels of NDF through the utilization of dehulled, degermed corn (DDC), corn (C), soybean meal (S), and distillers dried grains with solubles (DDGS). Diets were formulated to meet requirements relative to NRC (1998) recommendations. The same diet composition was used in each of 2 phases, with Phase-1 (P1) diets utilizing chromic oxide and Phase-2 diets (P2) utilizing titanium dioxide, each added at $5.0 \mathrm{~g} / \mathrm{kg}$ to the complete diet at the time of mixing to determine fecal marker concentrations. Two different inert markers were utilized to distinguish the feces originating from the diets consumed during P1 to the feces originating from the diet consumed in P2. This allows for the comparing the disappearance of the marker used in P1 and the appearance of the marker used in P2. This also prevents any potential contamination of the marker in the digestive tract in $\mathrm{P} 1$ with that of $\mathrm{P} 2$, which would have prevented the pre-planned comparisons of marker disappearance and appearance during the P2 period relative to a diet change. Pigs were provided ad libitum access to feed and water throughout the experiment.

\section{Pig management and collections}

Seventy two crossbred barrows [(Yorkshire $x$ Landrace $\times$ Duroc) $\times$ Chester White] were individually penned and randomly assigned to 1 of 3 dietary treatments. Pigs were initially separated into 3 treatment groupings of 24 pigs (d-0; $59.2 \mathrm{~kg} \mathrm{BW,} 4.81 \mathrm{~kg} \mathrm{SD}$ ) and fed ad libitum P1 diets for $14 \mathrm{~d}$ (d-14; $75.4 \mathrm{~kg} \mathrm{BW}, 5.71 \mathrm{~kg}$ SD) and then randomly reassigned within $\mathrm{P} 1$ dietary treatment into 1 of 3 P2 dietary treatments, and fed ad libitum an additional 14 days (d-28; $88.6 \mathrm{~kg} \mathrm{BW,} 5.46 \mathrm{~kg} \mathrm{SD})$, resulting in 9 treatment groups of 8 pigs each (Fig. 1). For each pig and each day during P2 (d-14 through d-28), freshly excreted fecal samples (samples either from the anus or after just dropping on the floor-but not contaminated with feed or existing feces) were collected into plastic containers and placed into a $-20{ }^{\circ} \mathrm{C}$ freezer until analyzed. Samples were collected from 0700 to $1200 \mathrm{~h}$ on
Table 1 Composition of Phase-1 and Phase-2 diets, as-fed basis ${ }^{a}$

\begin{tabular}{|c|c|c|c|}
\hline & DDC & $\mathrm{CS}$ & DDGS \\
\hline \multicolumn{4}{|l|}{ Ingredient, $\mathrm{g} / \mathrm{kg}$} \\
\hline Corn & - & 784.0 & 567.0 \\
\hline Soybean meal & 180.0 & 180.0 & 150.0 \\
\hline Dehulled, degermed corn & 781.9 & - & - \\
\hline Dried distillers grains with solubles & - & - & 250.0 \\
\hline Soybean oil & 5.0 & 5.0 & 5.0 \\
\hline L-Lysine $\cdot \mathrm{HCl}$ & 1.1 & - & - \\
\hline Dicalcium phosphate & 8.5 & 7.0 & 1.5 \\
\hline Limestone & 7.0 & 7.5 & 10.0 \\
\hline Sodium chloride & 5.0 & 5.0 & 5.0 \\
\hline Vitamin premix ${ }^{b}$ & 0.5 & 0.5 & 0.5 \\
\hline Trace mineral premix ${ }^{c}$ & 0.5 & 0.5 & 0.5 \\
\hline Marker $^{d}$ & 5.0 & 5.0 & 5.0 \\
\hline Clay $^{\mathrm{e}}$ & 5.0 & 5.0 & 5.0 \\
\hline Antibiotic $^{f}$ & 0.5 & 0.5 & 0.5 \\
\hline \multicolumn{4}{|c|}{ Calculated composition, $\mathrm{g} / \mathrm{kg}$ unless otherwise noted } \\
\hline Calcium & 5.0 & 5.0 & 5.0 \\
\hline Crude fat, & 12.0 & 41.0 & 53.0 \\
\hline Crude protein & 142.7 & 150.6 & 187.6 \\
\hline Lysine & 7.5 & 7.5 & 7.5 \\
\hline Metabolizable energy, kcal/kg & 3,293 & 3,332 & 3,193 \\
\hline NDF & 45.0 & 91.0 & 154.0 \\
\hline Phosphorus & 3.4 & 4.7 & 4.8 \\
\hline Sulfur & 1.0 & 1.8 & 2.1 \\
\hline \multicolumn{4}{|c|}{ Analyzed composition, $\mathrm{g} / \mathrm{kg}$ unless otherwise noted ${ }^{g}$} \\
\hline Crude fat & 12.8 & 37.2 & 47.7 \\
\hline Crude protein & 132.5 & 160.0 & 197.5 \\
\hline Gross energy, kcal/kg & 3,770 & 3,973 & 4,131 \\
\hline NDF & 25.1 & 72.5 & 125.0 \\
\hline Phosphorus & 2.8 & 4.6 & 4.9 \\
\hline Sulfur & 1.7 & 2.0 & 3.2 \\
\hline
\end{tabular}

${ }^{a}$ Abbreviations: DDC dehulled, degermed corn, CS corn, soybean meal, DDGS distillers dried grains with solubles

${ }^{b}$ Supplied per kilogram of diet: vitamin A, 6,600 IU; vitamin $D_{3}, 880 \mathrm{IU}$; vitamin $\mathrm{E}, 44 \mathrm{IU}$; vitamin $\mathrm{K}$ (menadione sodium bisulfate complex), $6.4 \mathrm{mg}$; thiamin, $4.0 \mathrm{mg}$; riboflavin, $8.8 \mathrm{mg}$; pyridoxine, $4.4 \mathrm{mg}$; vitamin $\mathrm{B}_{12}, 33 \mu \mathrm{g}$; folic acid, $1.3 \mathrm{mg}$; niacin, $44 \mathrm{mg}$; pantothenic acid, $22 \mathrm{mg}$; and D-biotin, $0.22 \mathrm{mg}$

'Supplied per kilogram of diet: $\mathrm{Zn}, 131 \mathrm{mg}$ as $\mathrm{ZnO} ; \mathrm{Fe}, 131 \mathrm{mg}$ as FeSO ${ }_{4} \cdot \mathrm{H}_{2} \mathrm{O}$; $\mathrm{Mn} 45 \mathrm{mg}$, as $\mathrm{MnO} ; \mathrm{Cu}, 13 \mathrm{mg}$ as $\mathrm{CuSO}_{4} \cdot 5 \mathrm{H}_{2} \mathrm{O} ; \mathrm{l}, 1.5 \mathrm{mg}$ as $\mathrm{Cal}_{2} \mathrm{O}_{6} ; \mathrm{Co}$, $0.23 \mathrm{mg}$ as $\mathrm{CoCO}_{3} ;$ and $\mathrm{Se}, 0.28 \mathrm{mg}$ as $\mathrm{Na}_{2} \mathrm{O}_{3} \mathrm{Se}$

${ }^{\mathrm{d}}$ The addition of $0.5 \%, \mathrm{Cr}_{2} \mathrm{O}_{3}$ ( $\geq 98 \%$ purity; Elementis Chromium LP, Corpus Christi, TX) represents an addition of $3.35 \mathrm{mg} \mathrm{Cr} / \mathrm{g}$ diet; averaged across diets, the analyzed content equaled $2.76 \mathrm{mg} \mathrm{Cr} / \mathrm{kg}$ diet (Phase-1). The addition of $0.5 \%$ TiO2 (99\% purity, Tronox Pigments GmBH, Krefield, Germany) represents an addition of $2.97 \mathrm{mg}$ titanium/g diet; averaged across diets, the analyzed content equaled $2.89 \mathrm{mg}$ titanium $/ \mathrm{kg}$ diet (Phase-2)

${ }^{\mathrm{e}} \mathrm{AB}-20$ (Prince Agriproducts, Quincy, IL)

${ }^{\mathrm{f}}$ Tylan-40 supplied $44 \mathrm{mg} / \mathrm{kg}$ of diet (Elanco, Greenfield, IN)

${ }^{9}$ Diets were analyzed at the USDA-ARS (Ames, IA), except for phosphorus which was analyzed by SDK Labs (Hutchison, KS) 


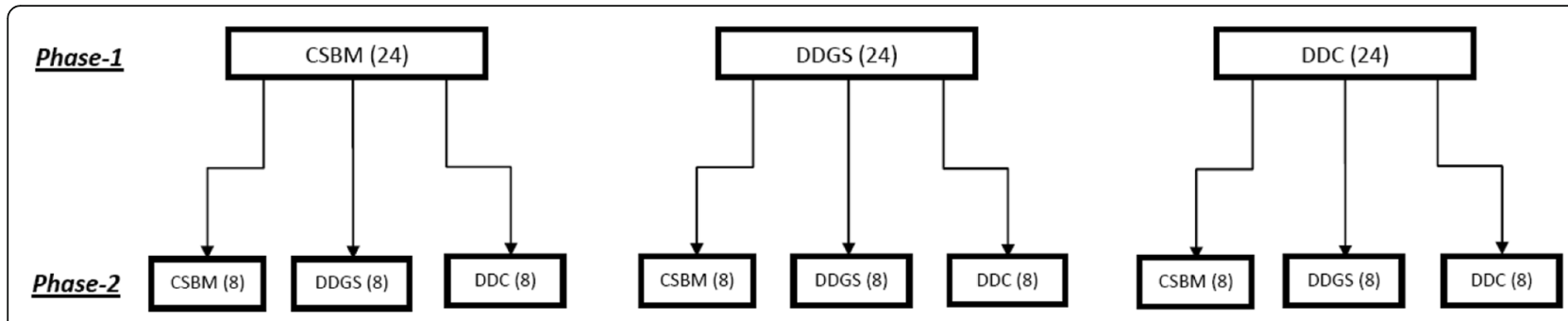

Fig. 1 Allotment of 72 crossbred barrows into Phase-1 ( 0 to 14) and Phase-2 ( 14 to 28) diets. DDC = dehulled, degermed corn; CSBM = corn, soybean meal; and DDGS = distillers dried grains with solubles. Numbers in parentheses represent the initial number of pigs per treatment

each collection day to be consistent in sample collection during the $14 \mathrm{~d}$ and to ensure an adequate sample size for subsequent analysis.

\section{Chemical analysis}

Prior to analysis, fecal samples were dried in a forced-air oven at $70{ }^{\circ} \mathrm{C}$ for $48 \mathrm{~h}$ prior to grinding. Feed and fecal samples were ground through a $1-\mathrm{mm}$ screen before composition was determined. Chromic oxide in feces was analyzed for $\mathrm{Cr}$ at a commercial laboratory (SDK Labs, Hutchinson, KS) by inductively coupled plasma spectroscopy (Ultima 2; Horiba Jobin-Yvon Inc., Edison, NJ) according to standard method (3120B; American Public Health Association, 1992) with a limit of quantitation (LOQ) of $0.3 \mathrm{mg} \mathrm{Cr} / \mathrm{kg}$ sample. Titanium dioxide in feces was analyzed for $\mathrm{Ti}$ by digesting the samples in sulfuric acid and hydrogen peroxide and subsequent absorbance was measured using a UV spectrophotometer (Method 988.05; [16]), with a LOQ of $6 \mathrm{mg} \mathrm{Ti/kg} \mathrm{sam-}$ ple (USDA-ARS, Ames, IA). Because reporting a zero (0) for data below the LOQ artificially skews analytical values to 0 , any value analyzed below the LOQ but above the limit of detection (values above the blank value used in standard curve assays), was assumed to be $50 \%$ of the LOQ, which is common in the chemical analysis industry.

\section{Calculations and statistical analysis}

All data were analyzed using mixed model methods using PROC MIXED (SAS Inst., Cary, NC). The model included P1 dietary treatment, P2 dietary treatment, and $\mathrm{P} 1 \times \mathrm{P} 2$ dietary interaction as fixed effects. For fecal $\mathrm{Cr}$ disappearance or $\mathrm{Ti}$ appearance during $\mathrm{P} 2$ as affected by the P1 diet, both $\mathrm{d}-14 \mathrm{BW}$ and $\mathrm{d}-8$ to 14 ADFI were used as model linear covariates [17]. However, for fecal Cr disappearance or Ti appearance during P2 as affected by the P2 diet, both d-14 BW and d-15 to 21 ADFI were used as model linear covariates. Only BW was utilized as a model linear covariate for the interaction between P1 and P2 diet. Regardless of significance, BW (which was often significant) and ADFI (which was often not significant) were retained in the model. Pig within treatment was included as a random effect in all models. Means are reported as least square means with fecal $\mathrm{Cr}$ or $\mathrm{Ti}$ concentrations plotted over time to show the disappearance of $\mathrm{Cr}$ and appearance of $\mathrm{Ti}$ during $\mathrm{P} 2$, relative to $\mathrm{P} 1$ or P2 diet composition. Fecal $\mathrm{Cr}$ or Ti concentrations for the final $7 \mathrm{~d}$ in $\mathrm{P} 2$, are not shown because there were

Table 2 Marker concentrations in corn-soybean meal diet containing either titanium dioxide, chromic oxide, or both titanium dioxide and chromic oxide ${ }^{a}$

\begin{tabular}{|c|c|c|}
\hline & Titanium, mg/kg diet & Chromium, mg/kg diet \\
\hline \multicolumn{3}{|l|}{ Diet $1-\mathrm{Cr}_{2} \mathrm{O}_{3}$} \\
\hline Sample 1 & 240 & 2,700 \\
\hline Sample 2 & 173 & 2,400 \\
\hline Sample 3 & 246 & 2,900 \\
\hline Sample 4 & 161 & 2,400 \\
\hline Mean & 205 & 2,600 \\
\hline SD & 44 & 245 \\
\hline$C V$ & 21.6 & 9.4 \\
\hline \multicolumn{3}{|l|}{ Diet $2-\mathrm{TiO}_{2}$} \\
\hline Sample 1 & 2,491 & $<0.01$ \\
\hline Sample 2 & 2,529 & $<0.01$ \\
\hline Sample 3 & 2,635 & $<0.01$ \\
\hline Sample 4 & 2,465 & $<0.01$ \\
\hline Mean & 2,530 & - \\
\hline SD & 75 & - \\
\hline CV & 3.0 & - \\
\hline \multicolumn{3}{|c|}{ Diet $3-\mathrm{Cr}_{2} \mathrm{O}_{3}$ and $\mathrm{TiO}_{2}$} \\
\hline Sample 1 & 2,942 & 2,400 \\
\hline Sample 2 & 2,831 & 2,500 \\
\hline Sample 3 & 2,995 & 2,800 \\
\hline Sample 4 & 2,768 & 2,700 \\
\hline Mean & 2,884 & 2,600 \\
\hline SD & 103 & 183 \\
\hline CV & 3.6 & 7.0 \\
\hline
\end{tabular}

The addition of $5,000 \mathrm{mg} \mathrm{Cr} \mathrm{O}_{3}$ added $\times 99.3 \%$ purity $\times 684 \mathrm{~g} / \mathrm{kg} \mathrm{Cr}$ would result in an expected level of $3,395 \mathrm{mg} \mathrm{Cr} / \mathrm{kg}$ diet. The addition of $5,000 \mathrm{mg}$ $\mathrm{TiO}_{2}$ added $\times 99.0 \%$ purity $\times 600 \mathrm{~g} / \mathrm{kg} \mathrm{Cr}$ would result in an expected level of 2,970 mg Ti/kg diet 
no changes in fecal $\mathrm{Cr}$ or $\mathrm{Ti}$ during that time period or the levels were below LOQ. Estimates of the number of days for fecal Cr to decrease to the LOQ or for fecal Ti to reach $95 \%$ of its maximum value for each P1 $\times$ P2 combination was determined fitting a 4 parameter sigmoidal logistic function $\left[\left(y=D+\frac{(A-D)}{1+\left(\frac{x}{C}\right)^{B}}\right)\right.$; where $x=$ collection time, $y=$ the response value ( $\mathrm{Cr}$ or $\mathrm{Ti}$ concentration), $\mathrm{A}=$ minimum point in the line $\mathrm{B}=$ slope in the middle of the curve, $\mathrm{C}=$ point of inflection, $\mathrm{D}=$ maximum of the line; Microsoft Excel 2010] to the overall treatment means.

\section{Results}

Dual marker recovery

A critical factor for the present study was that analysis of $\mathrm{Cr}$ and $\mathrm{Ti}$ in the same diet would not interfere with the analysis of either element. To evaluate this, 3 separate corn-soybean meal diets were mixed which contained either $5 \mathrm{~g}$ chromic oxide/ $\mathrm{kg}$ diet (Diet 1), $5 \mathrm{~g}$ titanium dioxide/ $\mathrm{kg}$ diet (Diet 2), or both $5 \mathrm{~g}$ chromic oxide and $5 \mathrm{~g}$ titanium dioxide/kg diet (Diet 3). Although $\mathrm{Cr}$ analysis was lower than expected averaging 2,600 $\mathrm{mg} \mathrm{Cr} / \mathrm{kg}$ diet versus an expected level of 3,395 $\mathrm{mg} \mathrm{Cr} / \mathrm{kg}$ diet $(5,000 \mathrm{mg}$ $\mathrm{Cr}_{2} \mathrm{O}_{3}$ added $\times 99.3 \%$ purity $\times 684 \mathrm{~g} / \mathrm{kg} \mathrm{Cr}$ ), it did not differ whether added either alone (Diet 1) or with titanium dioxide (Diet 3), Table 2. Titanium in Diets 2 and 3 averaged 2,502 $\mathrm{mg} / \mathrm{kg}$ diet after subtracting out the apparent background Ti level noted in Diet 1 . This too was lower than the expected value of $2,970 \mathrm{mg} \mathrm{Ti} / \mathrm{kg}$ diet $(5,000 \mathrm{mg}$ $\mathrm{TiO}_{2}$ added $\times 99.0 \%$ purity $\times 600 \mathrm{~g} / \mathrm{kg} \mathrm{Ti}$. . There were slight differences in Ti levels between Diet 2 (2,530 mg Ti/ $\mathrm{kg}$ diet) with only $\mathrm{TiO}_{2}$ added, and Diet $3(2,884 \mathrm{mg} \mathrm{Ti} / \mathrm{kg}$ diet) when both and $\mathrm{Cr}_{2} \mathrm{O}_{3}$ and $\mathrm{TiO}_{2}$.

Table 3 Fecal chromium (mg/g fecal DM) of growing pigs during Phase-2 when fed different diets during Phase-1 and Phase-2

\begin{tabular}{|c|c|c|c|c|c|c|c|c|c|}
\hline \multicolumn{2}{|c|}{ Phase $\times$ diet combinations } & \multicolumn{8}{|c|}{ Collection day ${ }^{b}$} \\
\hline Phase-1 & Phase-2 & 14 & 15 & 16 & 17 & 18 & 19 & 20 & 21 \\
\hline $\mathrm{CS}^{\mathrm{a}}$ & CS & 21.6 & 20.2 & 16.2 & 3.2 & 0.6 & $\operatorname{LOQ}^{c}$ & LOQ & LOQ \\
\hline CS & DDGS & 17.8 & 20.6 & 17.7 & 1.1 & 0.4 & LOQ & LOQ & LOQ \\
\hline CS & DDC & 19.5 & 21.4 & 18.0 & 5.7 & 1.8 & 0.8 & 0.3 & LOQ \\
\hline DDGS & CS & 15.3 & 15.4 & 10.7 & 0.4 & LOQ & LOQ & LOQ & LOQ \\
\hline DDGS & DDGS & 14.2 & 15.8 & 11.3 & 0.3 & LOQ & LOQ & LOQ & LOQ \\
\hline DDGS & DDC & 15.3 & 17.5 & 18.2 & 9.7 & 2.4 & 0.4 & 0.3 & LOQ \\
\hline DDC & CS & 60.4 & 60.8 & 32.8 & 0.6 & LOQ & LOQ & LOQ & LOQ \\
\hline DDC & DDGS & 64.0 & 55.8 & 26.3 & 3.0 & LOQ & LOQ & LOQ & LOQ \\
\hline DDC & DDC & 63.5 & 60.4 & 32.3 & 8.3 & 1.5 & 0.4 & LOQ & LOQ \\
\hline SE & & 2.47 & 2.85 & 4.92 & 2.21 & 0.35 & 0.11 & 0.04 & 0.02 \\
\hline Interaction $P$ value & & 0.01 & 0.01 & 0.01 & 0.02 & 0.01 & 0.01 & 0.01 & 0.01 \\
\hline \multicolumn{10}{|c|}{ Main effect of Phase-1 diet } \\
\hline Phase-1 & Phase-2 & & & & & & & & \\
\hline CS & CS/DDGS/DDC & 20.1 & 20.1 & 17.4 & 3.5 & 0.9 & 0.3 & LOQ & LOQ \\
\hline DDGS & CS/DDGS/DDC & 15.5 & 16.2 & 13.8 & 3.6 & 0.9 & LOQ & LOQ & LOQ \\
\hline DDC & CS/DDGS/DDC & 62.5 & 58.6 & 30.1 & 3.8 & 0.6 & LOQ & LOQ & LOQ \\
\hline SE & & 1.00 & 1.45 & 2.82 & 1.37 & 0.36 & 0.10 & 0.04 & 0.03 \\
\hline$P$ value & & 0.01 & 0.01 & 0.01 & 0.98 & 0.76 & 0.46 & 0.28 & 0.60 \\
\hline \multicolumn{10}{|c|}{ Main effect of Phase-2 diet } \\
\hline Phase-1 & Phase-2 & & & & & & & & \\
\hline CS/DDGS/DDC & CS & 29.9 & 26.4 & 20.0 & 1.6 & 0.3 & LOQ & LOQ & LOQ \\
\hline CS/DDGS/DDC & DDGS & 31.9 & 29.2 & 18.9 & 2.0 & 0.3 & LOQ & LOQ & LOQ \\
\hline CS/DDGS/DDC & DDC & 31.8 & 34.3 & 22.4 & 7.7 & 1.9 & 0.5 & 0.3 & LOQ \\
\hline SE & & 5.75 & 6.08 & 3.85 & 1.06 & 0.21 & 0.01 & 0.02 & 0.01 \\
\hline$P$ value & & 0.95 & 0.57 & 0.81 & 0.01 & 0.01 & 0.01 & 0.01 & 0.01 \\
\hline
\end{tabular}

a Abbreviations: CS corn-soybean meal based diet, DDGS corn-soybean meal-distillers dried grains based diet, $D D C$ dehulled, degermed corn-soybean meal based diet. For Phase-1, ADFI from d 1 to 14 was $2.94,2.79$, and $2.66 \mathrm{~kg}$ (SE $=0.07 \mathrm{~kg}$ ) for pigs fed the DDC, CS, and DDGS diets, respectively. For Phase-2, ADFI from d 14 to 28 was $2.91,2.84$, and $2.63 \mathrm{~kg}(\mathrm{SE}=0.21 \mathrm{~kg}$ ) for pigs fed the DDC, CS, and DDGS diets, respectively

${ }^{b}$ Collection day following change from Phase- 1 to Phase-2 diet, with $\mathrm{d} 14$ representing the last day of the diet containing the $\mathrm{Cr}$ marker was fed

${ }^{\mathrm{L}} \mathrm{LOQ}=$ limit of quantitation; $0.3 \mathrm{mg} \mathrm{Cr} / \mathrm{kg}$; with $1 / 2 \mathrm{LOQ}$ used for statistical analysis 


\section{Fecal $\mathrm{Cr}$ disappearance}

Interactions occurred between P1 and P2 diets on fecal $\mathrm{Cr}$ disappearance $(P<0.01)$ during $\mathrm{P} 2$, with specific values and significance levels listed in Table 3 and graphically depicted in Fig. 2a. Averaged across diet changes, when dietary NDF was increased in the diets fed to pigs from P1 to P2 (i.e., pigs fed the CS diet

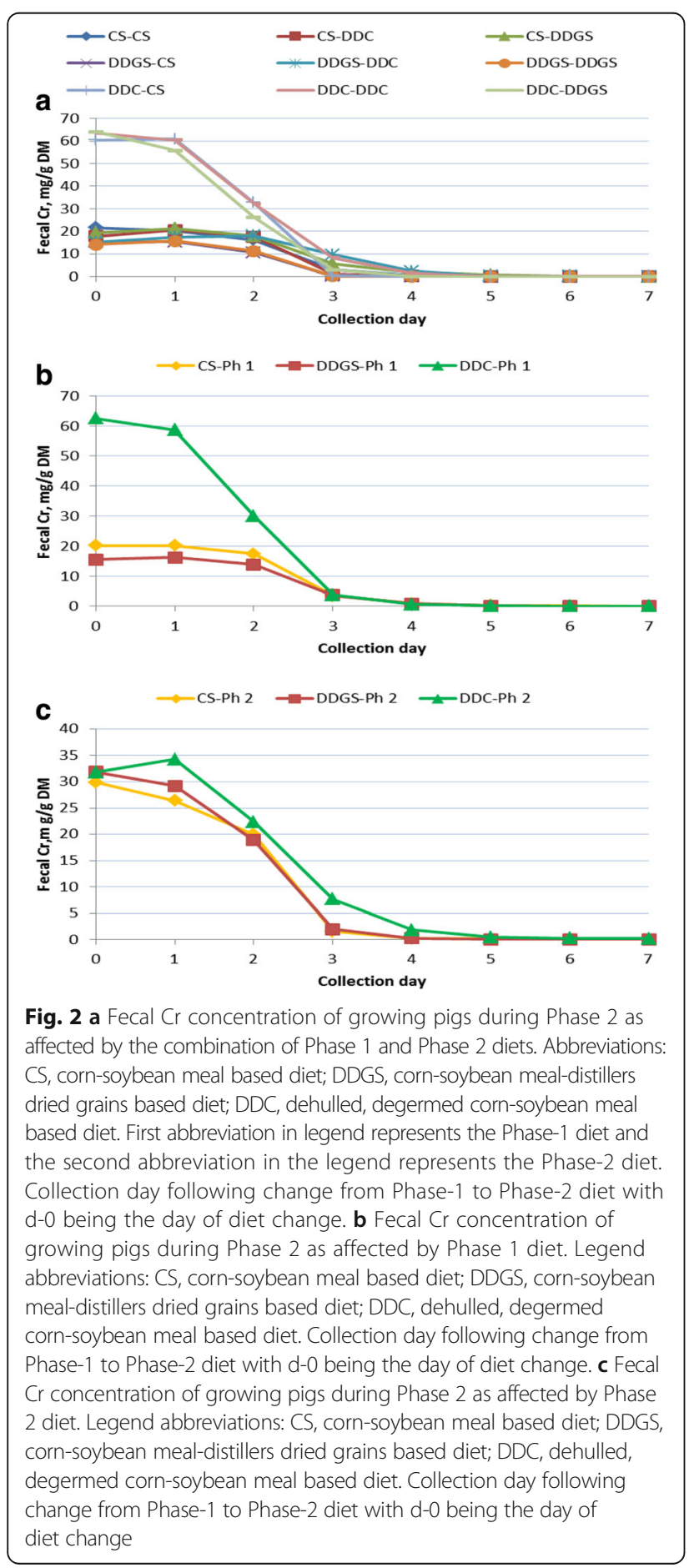

switched to the DDGS diet and pigs fed the DDC diet switched to either the CS or DDGS diet), it took $2.6 \mathrm{~d}$ for each 5 percentage unit increase in NDF for P2 fecal $\mathrm{Cr}$ to decrease below the LOQ of $0.3 \mathrm{mg} / \mathrm{kg}$ fecal DM. In contrast, when dietary NDF was decreased in the diets fed to pigs from P1 to P2 (i.e., pigs fed the CS diet switched to the DDC diet and pigs fed the DDGS diet switched to either the CS or DDC diet), it took $3.5 \mathrm{~d}$ for each 5 percentage unit decrease in NDF for P2 fecal $\mathrm{Cr}$ to decrease below the LOQ (Tables 3 and 5). When pigs remained on the same diets from P1 to P2, pigs continually fed the DDC diet containing $25.1 \mathrm{~g} / \mathrm{kg}$ NDF took 5.1 $\mathrm{d}$ for P2 fecal $\mathrm{Cr}$ to decrease below the LOQ, while pigs fed the CS diet containing $72.5 \mathrm{~g} / \mathrm{kg}$ NDF and the DDGS diet containing $125.0 \mathrm{~g} / \mathrm{kg}$ NDF took $4.1 \mathrm{~d}$ and $2.5 \mathrm{~d}$, respectively, for P2 fecal Cr to decrease below the LOQ (Tables 3 and 5).

The main effect of the P1 diet on P2 fecal Cr concentration is reported in Table 3 and graphically depicted in Fig. 2b. For $d-14$ and the following $2 \mathrm{~d}$, pigs fed the DDC diet in P1 had a greater P2 fecal Cr concentration of than for pigs fed either the CS or DDGS diet, with pigs fed the CS diet having a higher P2 fecal Cr than pigs fed the DDGS diet for $\mathrm{d}-14$ and $\mathrm{d}-15$, but equal on d-16. No dietary differences were noted thereafter. The main effect of P2 diet on P2 fecal Cr concentration is additionally reported in Table 3 and graphically depicted in Fig. 2c. Phase 2 diets had no impact on P2 fecal $\mathrm{Cr}$ concentration among pigs fed the diets for $\mathrm{d}-14$ through $\mathrm{d}-16$, with pigs fed the DDC diet having a higher P2 fecal Cr concentration than pigs fed either the CS or DDGS diets on $\mathrm{d}-17$ and $\mathrm{d}-18$, with no differences in $\mathrm{P} 2$ fecal $\mathrm{Cr}$ concentration between pigs fed the CS or DDGS diets. Subsequent to d-18, P2 fecal Cr fell below the LOQ for pigs fed the CS or the DDGS diet, but did not decrease below the LOQ in pigs fed the DDC diet until d-21.

\section{Fecal Ti appearance}

Similar to that observed for fecal $\mathrm{Cr}$ disappearance, interactions were noted between P1 and P2 diets on fecal Ti appearance during P2, with specific values and significance levels listed in Table 4, and graphically depicted in Fig. 3a. Averaged across diet changes, when dietary NDF was increased in the diets fed to pigs from P1 to P2 (i.e., pigs fed the CS diet switched to the DDGS diet and pigs fed the DDC diet switched to either the CS or DDGS diet), it took $2.4 \mathrm{~d}$ for each 5 percentage units increase in NDF for P2 fecal Ti to approach its maximum level. In contrast, when dietary NDF was decreased in the diets fed to pigs from P1 to P2 (i.e., pigs fed the CS diet switched to the DDC diet and pigs fed the DDGS diet switched to either the CS or DDC diet), it took $3.2 \mathrm{~d}$ for each 5 percentage units decrease in NDF for P2 fecal Ti to approach its maximum level (Tables 4 and 5). When 
Table 4 Fecal titanium (mg/g fecal DM) of growing pigs during Phase-2 when fed different diets during Phase-1 and Phase-2

\begin{tabular}{|c|c|c|c|c|c|c|c|c|c|}
\hline \multicolumn{2}{|c|}{ Phase $\times$ diet combinations } & \multicolumn{8}{|c|}{ Collection day ${ }^{\mathrm{b}}$} \\
\hline Phase-1 & Phase-2 & 14 & 15 & 16 & 17 & 18 & 19 & 20 & 21 \\
\hline$\overline{C S^{a}}$ & CS & $\mathrm{LOQ}^{\mathrm{C}}$ & LOQ & 7.3 & 22.0 & 25.9 & 28.1 & 27.4 & 24.8 \\
\hline CS & DDGS & LOQ & LOQ & LOQ & 15.4 & 15.9 & 17.9 & 18.3 & 16.1 \\
\hline CS & DDC & LOQ & LOQ & 10.1 & 45.6 & 56.7 & 60.6 & 58.1 & 58.8 \\
\hline DDGS & CS & LOQ & LOQ & 9.2 & 22.9 & 25.6 & 25.5 & 26.2 & 25.7 \\
\hline DDGS & DDGS & LOQ & LOQ & 6.5 & 16.8 & 16.1 & 17.2 & 18.7 & 16.4 \\
\hline DDGS & DDC & LOQ & LOQ & LOQ & 34.9 & 55.6 & 59.8 & 61.4 & 62.1 \\
\hline DDC & CS & LOQ & LOQ & 10.0 & 24.2 & 22.2 & 23.2 & 23.8 & 23.4 \\
\hline DDC & DDGS & LOQ & LOQ & 9.7 & 17.3 & 17.9 & 17.6 & 18.9 & 19.1 \\
\hline DDC & DDC & LOQ & LOQ & 26.5 & 50.4 & 64.0 & 65.3 & 65.2 & 68.3 \\
\hline SE & & 0.11 & 0.58 & 2.82 & 1.87 & 2.06 & 2.16 & 1.81 & 2.06 \\
\hline Interaction $P$ value & & 0.01 & 0.83 & 0.01 & 0.01 & 0.01 & 0.01 & 0.01 & 0.01 \\
\hline \multicolumn{10}{|c|}{ Main effect of Phase-1 diet } \\
\hline Phase-1 & Phase-2 & & & & & & & & \\
\hline CS & CS/DDGS/DDC & LOQ & LOQ & 8.2 & 26.6 & 31.4 & 33.1 & 32.2 & 31.1 \\
\hline DDGS & CS/DDGS/DDC & LOQ & LOQ & 6.1 & 23.5 & 32.1 & 33.2 & 34.2 & 34.0 \\
\hline DDC & CS/DDGS/DDC & LOQ & LOQ & 15.7 & 31.8 & 33.6 & 35.7 & 34.8 & 37.9 \\
\hline SE & & 0.06 & 0.20 & 2.62 & 3.67 & 4.74 & 3.99 & 5.08 & 5.31 \\
\hline$P$ value & & 0.01 & 0.01 & 0.03 & 0.22 & 0.93 & 0.88 & 0.91 & 0.61 \\
\hline \multicolumn{10}{|c|}{ Main effect of Phase-2 diet } \\
\hline Phase-1 & Phase-2 & & & & & & & & \\
\hline CS/DDGS/DDC & CS & LOQ & LOQ & 9.9 & 23.1 & 24.8 & 25.5 & 26.1 & 25.3 \\
\hline $\mathrm{CS} / \mathrm{DDGS} / \mathrm{DDC}$ & DDGS & LOQ & LOQ & 10.0 & 17.4 & 18.9 & 19.8 & 19.9 & 19.7 \\
\hline CS/DDGS/DDC & DDC & LOQ & LOQ & 10.9 & 42.6 & 56.3 & 60.1 & 60.8 & 61.3 \\
\hline SE & & 0.17 & 0.36 & 2.86 & 1.52 & 0.70 & 0.81 & 0.78 & 0.76 \\
\hline$P$ value & & 0.79 & 0.48 & 0.96 & 0.01 & 0.01 & 0.01 & 0.01 & 0.01 \\
\hline
\end{tabular}

pigs remained on the same diets from P1 to P2, pigs continually fed the DDC diet containing $25.1 \mathrm{~g} / \mathrm{kg} \mathrm{NDF}$ took $4.6 \mathrm{~d}$ for P2 fecal $\mathrm{Ti}$ to reach $95 \%$ of the maximum level, while pigs fed the CS diet containing $72.5 \mathrm{~g} / \mathrm{kg}$ $\mathrm{NDF}$ and the DDGS diet containing $125.0 \mathrm{~g} / \mathrm{kg} \mathrm{NDF}$ took $3.7 \mathrm{~d}$ and $2.8 \mathrm{~d}$, respectively, for $\mathrm{P} 2$ fecal $\mathrm{Ti}$ to reach $95 \%$ of its maximum level (Tables 4 and 5 ).th=tlb=

The main effect of the P1 diet on P2 fecal Ti concentration is reported in Table 4 and graphically depicted in Fig. 3b. Prior to d-16, fecal Ti was below the laboratory LOQ of $6 \mathrm{mg} / \mathrm{kg}$ fecal DM. On d-16, P2 fecal Ti for pigs fed the DDC diet in P1 was greater than for pigs fed the CS or DDGS diets, with no difference observed in P2 fecal $\mathrm{Ti}$ between pigs fed the CS and DDGS diets. After d-16, diets fed during P1 had no effect on P2 fecal Ti concentrations. The main effect of P2 diet on P2 fecal Ti concentration is reported in Table 4 and graphically depicted in Fig. 3c. There were no differences observed between P2 fecal Ti concentrations among pigs fed the diets for d-14 through d-16. From d-17 through d-21, pigs fed the DDC diet during P2 had a higher P2 fecal Ti concentration than pigs fed either the CS or DDGS diets, and pigs fed the CS diet had a higher P2 fecal Ti concentration when compared to pigs fed the DDGS diets.

\section{Discussion}

Others [18-20] have reviewed criteria necessary for the use of markers in digestibility studies, but in addition to these, a critical factor for the present study was that analysis of $\mathrm{Cr}$ and $\mathrm{Ti}$ in the same diet would not interfere 


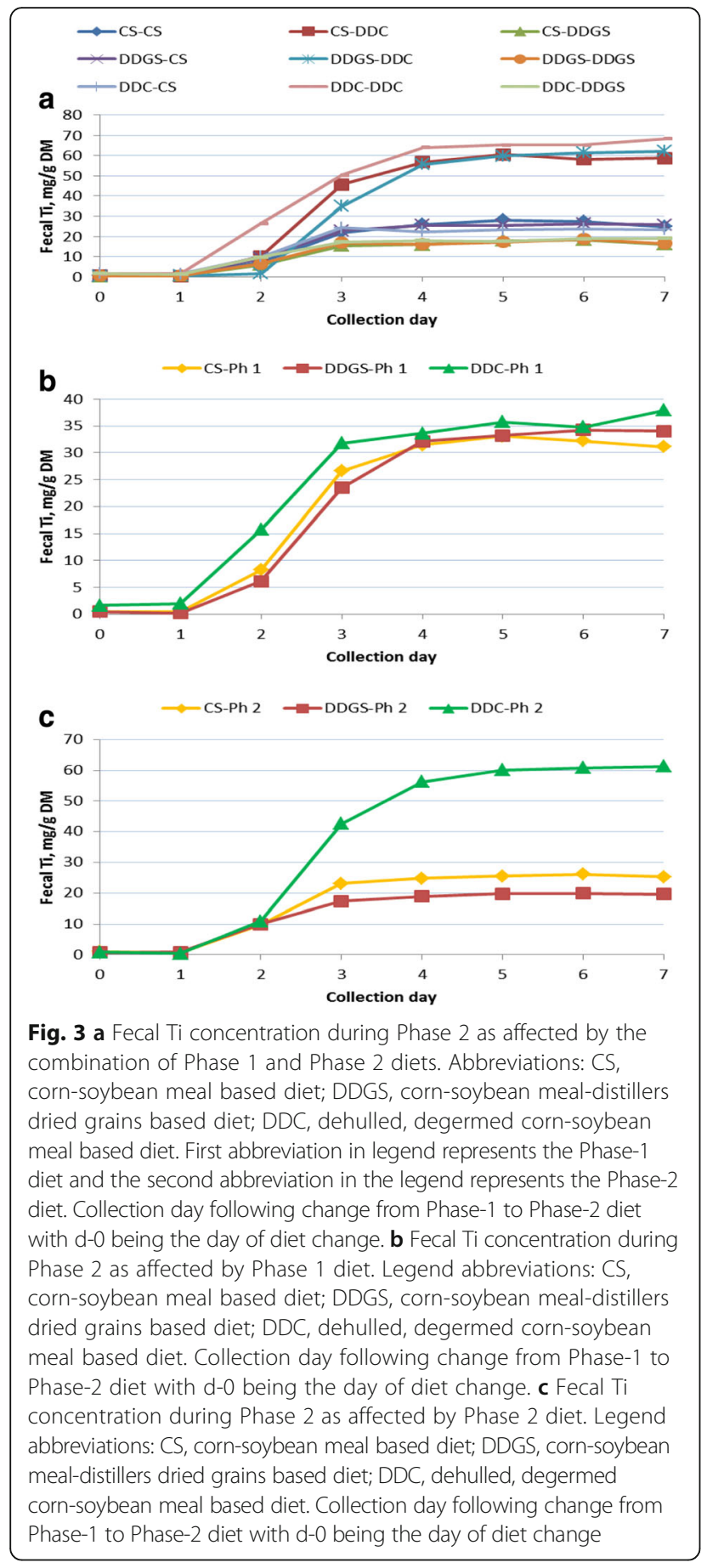

with the analysis of either element. Full recovery of $\mathrm{Cr}$ $[20,21]$ and $\mathrm{Ti}[22,23]$ has been shown to be problematic, which was the case in our dual marker recovery experiment $(\mathrm{Cr}$ recovery of $77 \%$, $\mathrm{Ti}$ recovery of $84 \%$; Table 2) and animal experiment (Cr recovery of $82 \%, \mathrm{Ti}$ recovery of $97 \%$; Table 1) as well. The lack of any major differences in recovery of dual markers in our experiment is supported by others $[24,25]$ who have noted little impact of dual markers on individual marker
Table 5 Sigmoidal response parameters for $\mathrm{P} 2 \mathrm{fecal} \mathrm{Cr}$ disappearance and P2 fecal Ti appearance for growing pigs fed different diets during Phase-1 and Phase-2

\begin{tabular}{|c|c|c|c|c|}
\hline \multicolumn{2}{|c|}{$\begin{array}{l}\text { Phase } \times \text { diet } \\
\text { combinations }\end{array}$} & \multirow{2}{*}{$\begin{array}{l}\text { NDF } \triangle \\
\% \\
\text { Units }{ }^{\mathrm{b}}\end{array}$} & \multirow{2}{*}{$\begin{array}{l}\text { Fecal } \mathrm{Cr} \\
\text { disappearance, } \\
\mathrm{d} \text { reach limit of } \\
\text { quantitation }\end{array}$} & \multirow{2}{*}{$\begin{array}{l}\text { Fecal } \mathrm{Ti} \\
\text { appearance, } \\
\mathrm{d} \text { to reach } 95 \% \\
\text { maximum }\end{array}$} \\
\hline $\begin{array}{l}\text { Phase- } \\
1\end{array}$ & $\begin{array}{l}\text { Phase- } \\
2\end{array}$ & & & \\
\hline$\overline{C S^{a}}$ & CS & 0 & 4.1 & 3.7 \\
\hline CS & DDGS & +5.25 & 3.3 & 3.5 \\
\hline CS & DDC & -4.74 & 4.9 & 3.9 \\
\hline DDGS & CS & -5.25 & 3.1 & 3.5 \\
\hline DDGS & DDGS & 0 & 2.5 & 2.8 \\
\hline DDGS & DDC & -9.99 & 4.8 & 4.2 \\
\hline DDC & CS & +4.74 & 2.6 & 2.2 \\
\hline DDC & DDGS & +9.99 & 3.8 & 3.2 \\
\hline DDC & DDC & 0 & 5.1 & 4.6 \\
\hline
\end{tabular}

${ }^{a}$ Abbreviations: CS corn-soybean meal based diet, DDGS corn-soybean mealdistillers dried grains based diet, $D D C$ dehulled, degermed corn-soybean meal based diet

${ }^{\mathrm{b}}$ Change in analyzed dietary NDF, percentage units

${ }^{C}$ As determined by sigmoidal response of phase $x$ diet treatment means obtained from Table 3. The $\mathrm{Cr}$ limit of quantitation was $0.3 \mathrm{mg} \mathrm{Cr} / \mathrm{kg}$ ${ }^{d}$ As determined by sigmoidal response of phase $\times$ diet treatment means obtained from Table 4. The Ti limit of quantitation was $6 \mathrm{mg} \mathrm{Ti} / \mathrm{kg}$

recovery. Nonetheless, despite any potential differences in marker recovery, we believe that the data obtained in our animal experiment is valid in determining the time from which a new collection period could begin without the previous marker interfering with the results obtained in the subsequent collection period. Taken together, the literature and our data suggest that use of two markers within the digestive tract does not compromise or confound the results that we obtained in our animal experiment. We also chose to sample pigs at the same time each day to eliminate any confounding effects relative to diurnal variation in fecal composition that has been previously reported $[12,26,27]$.

Numerous experiments have been conducted to describe the time of first or $5 \%$ marker appearance $[4,5$, $11,28]$, mean transit rate $[6,8,28-31]$ or $25,50,80$, or $95 \%$ of the marker excreted $[4,5,7]$; values which are useful in mathematical modeling of digestion [3]. This was not the focus of our experiment as we chose to only determine when P2 fecal Cr reached its minimum LOQ and when P2 fecal Ti reached 95\% of its maximum because we were interested in if the previous or present diet affected when a dietary marker was completely excreted (Cr, Table 3) or stabilized (Ti, Table 4).

It is well known that the dietary fiber type and level affects rate of passage [6-8]. These effects were not, however, independent from the previous diet fed as indicated by the interaction between diets fed during P1 and P2. The current data indicate that as dietary NDF increased from P1 to P2, it took less time for P2 fecal Cr to decrease 
(2.6 d) or P2 fecal Ti to be maximized (2.4 d), than if NDF was decreased from P1 to P2, where it took $3.5 \mathrm{~d}$ for P2 fecal $\mathrm{Cr}$ to decrease or $3.2 \mathrm{~d}$ for P2 fecal Ti to be maximized. These effects were independent from feed intake in the current study because in most instances ADFI was not a significant covariate (although ADFI was still retained in the model to eliminate even minimal feed intake differences). Differences in P2 fecal marker concentration ( $\mathrm{Cr}$ or $\mathrm{Ti}$ in the current study) by diet type were expected due to digestibility differences among ingredients utilized in diet formulations. With components in the diets digested to different degrees but the marker remaining undigested, subsequent $\mathrm{Cr}$ or $\mathrm{Ti}$ concentration should have changed proportionally. In the current experiment, pigs fed the diet having the greatest digestibility (DDC) resulted in the greatest fecal marker concentration, followed by pigs fed the CS diet, and lastly, by pigs fed the DDGS diet.

\section{Conclusions}

Overall, data from the present study indicate that as the digestibility of the diets increased (i.e., decreasing dietary $\mathrm{NDF}$ ), it took progressively longer for $\mathrm{P} 2 \mathrm{fecal} \mathrm{Cr}$ to be excreted or P2 fecal Ti to be maximized (approximately $2.5 \mathrm{~d}$ ) than if diets that were decreasing in digestibility (i.e., increasing dietary NDF) were fed (approximately $3.4 \mathrm{~d}$ ), a difference of approximately $1 \mathrm{~d}$. For pigs fed diets containing a moderate amount of DDGS or only corn and soybean meal, the complete elimination of $\mathrm{Cr}$ in $\mathrm{P} 2$ feces or maximum appearance of $\mathrm{Ti}$ in $\mathrm{P} 2$ feces was approximately 3 and $4 \mathrm{~d}$, respectively. In contrast, pigs fed diets containing highly digestible ingredients such as DDC (or semi-purified diets as are used in some experimental methodologies) took longer for clearance or equilibrium, approximately $5 \mathrm{~d}$ in the current experiment. This information is critical to know when pigs are utilized either once or for multiple times in digestibility experiments containing inert makers, and suggest that caution must be taken so as to not have previous dietary marker addition remain in the digestive tract or feces to confound subsequent experimental results.

\section{Abbreviations \\ ADFI: Average daily feed intake; BW: Body weight; C: Corn; Cr: Chromium; CV: Coefficient of variation; d: Day; DDC: Dehulled ddgermed corn; DDGS: Distillers dried grains with solubles; h: Hour; LOQ: Limit of quantitation; NDF: Neutral detergent fiber; P1: Phase 1; P2: Phase 2; S: Soybean meal; SD: Standard deviation; Se: Standard error; Ti: Titanium}

\section{Acknowledgements}

The authors express thanks to J. Cook at the National Laboratory for Agriculture and the Environment (Ames, lowa) for laboratory assistance. Appreciation is also expressed to H. J. Monegue and W. Patton (University of Kentucky, Lexington) for assistance in the care of pigs and to D. Higginbotham (University of Kentucky, Lexington) for help in diet preparation; and to Akey Inc. (Lewisburg, $\mathrm{OH})$ and DSM Nutritional Products Inc. (Parsippany, NJ) for ingredients used in the diets. Mention of a trade name, proprietary product, or specific equipment does not constitute a guarantee or warranty by the USDA, lowa State University, or the University of Kentucky and does not imply approval to the exclusion of other products that may be suitable. The USDA is an equal opportunity provider and employer.

\section{Funding}

No external funds were used in the design, collection, analysis, interpretation, or writing of this manuscript.

\section{Availability of data and materials}

The dataset supporting the conclusions of this article is included within the article.

\section{Authors' contributions}

BMJ, MDL, and BJK conceived and performed the experiment. All authors assisted in data analysis, interpreting and proofing the manuscript, and approving the final version of the manuscript.

\section{Competing interests}

The authors declare that they have no conflicts of interests that could be perceived as prejudicing the impartiality of this paper.

\section{Consent for publication \\ Not applicable.}

Ethics approval and consent to participate

All procedures conducted under protocols approved by the University of Kentucky Institutional Animal Care and Use Committee, Lexington, Kentucky.

\section{Author details}

'Department of Animal Science, lowa State University, Ames 50010, USA. ${ }^{2}$ Department of Animal and Food Sciences, University of Kentucky, Lexington 40546, KY, USA. ${ }^{3}$ USDA-ARS-National Laboratory for Agricultural and the Environment, Ames 50010, IA, USA.

Received: 7 September 2016 Accepted: 21 March 2017

Published online: 01 April 2017

\section{References}

1. Adeola A. Digestion and balance techniques in pigs. In: Lewis AJ, Southern LL, editors. Swine nutrition. Boca Raton: CRC Press; 2001. p. 903-16.

2. Low AG. Nutritional regulation of gastric secretion, digestion and emptying. Nutr Res Rev. 1990;3:229-52.

3. Bastianelli D, Sauvant D, Rerat A. Mathematical modeling of digestion and nutrient absorption in pigs. J Anim Sci. 1996;74:1879-87.

4. Castle EJ, Castle ME. The rate of passage of food through the alimentary tract of pigs. J Agric Sci. 1956;47:196-203.

5. Castle EJ, Castle ME. Further studies of the rate of passage of food through the alimentary tract of pigs. J Agric Sci. 1957;49:106-12.

6. Cherbut C, Barry JJL, Wyers M, Delort-Laval J. Effect of the nature of dietary fibre on transit time and faecal excretion in the growing pig. Anim Feed Sci Technol. 1988;20:327-33.

7. Freire JPB, Guerreiro AJG, Cunha LF, Aumaitre A. Effect of dietary fibre source on total tract digestibility, caecum volatile fatty acids and digestive transit time in the weaned piglet. Anim Feed Sci Technol. 2000;87:71-83.

8. Le Goff G, van Milgen J, Noblet J. Influence of dietary fibre on digestive utilization and rate of passage in growing pigs, finishing pigs and adult sow. Anim Sci. 2002;74:503-15.

9. Potkins ZV, Lawrence TLJ, Thomlinson JR. Effects of structural and nonstructural polysaccharides in the diet of the growing pig on gastric emptying rate and rate of passage of digesta to the terminal ileum and through the total gastrointestinal tract. Br J Nutr. 1991;65:391-413.

10. Varel $\mathrm{VH}$, Jung $\mathrm{HG}$, Pond WG. Effects of dietary fiber of young adult genetically lean, obese and contemporary pigs: rate of passage, digestibility and microbiological data. J Anim Sci. 1988;66:707-12.

11. Holzgraefe DP, Fahey Jr GC, Jensen AH. Influence of dietary alfalfa: orchardgrass hay and lasalocid on in vitro estimates of dry matter digestibility and volatile fatty acid concentrations of cecal contents and rate of digesta passage in sows. J Anim Sci. 1985;60:1235-46.

12. Jorgensen $H$, Lindberg JE, Andersson C. Diurnal variation in the composition of ileal digesta and the ileal digestibilities of nutrients in growing pigs. J Sci Food Agric. 1997;74:244-50.

13. Imbeah M, Sauer WC, Caine WR. Comparison of the single dose and withdrawal method for measuring the rate of passage of two digestibility markers in digesta collected form the distal ileum and feces in growing pigs. Anim Feed Sci Technol. 1995;52:41-50. 
14. Clawson AJ, Reid JT, Sheffy BE, Willman JP. Use of chromium oxide in digestion studies with swine. J Anim Sci. 1955;14:700-9.

15. Agudelo JH, Lindemann MD, Cromwell GK. A comparison of two methods to assess nutrient digestibility in pigs. Livest Sci. 2010;133:74-7.

16. Association of Official Analytical Chemists (AOAC). Official methods of analysis. 9th ed. Washington, DC: AOAC; 1978.

17. Jacobs BM, Patience JF, Lindemann MD, Stalder K, Kerr BJ. The use of covariate reduces experimental error in nutrient digestion studies in growing pigs. J Anim Sci. 2013;91:804-10.

18. Kotb AR, Luckey TD. Markers in nutrition. Nutr Abstr Rev. 1972;42:813-45.

19. Saha DC, Gilbreath RL. Analytical recovery of chromium from the diet and faeces determined by colorimetry and atomic absorption spectrophotometry. J Sci Food Agric. 1991;55:433-46.

20. Jagger S, Wiseman J, Cole DJA, Craigon J. Evaluation of inert markers for the determination of ileal and faecal apparent digestibility values in the pig. $\mathrm{Br} J$ Nutr. 1992;68:729-39.

21. Carciofi AC, Vasconcellos RS, de Oliveira LD, Brunetto MA, Valerio AG, Baxolli RS, et al. Chromic oxide as a digestibility marker for dogs - a comparison of methods of analysis. Anim Feed Sci Technol. 2007;134:273-82.

22. Yin JL, McEvoy DG, Schulze H, McCracken KJ. Studies on cannulation method and alternative indigestible markers and the effects of food enzyme supplementation in barley-based diets on ileal and overall apparent digestibility in growing pigs. Anim Sci. 2000;70:63-72.

23. Yin JL, McEvoy JDG, Schulze H, Henning U, Souffrant WB, McCracken KJ. Apparent digestibility (ileal and overall) of nutrients as evaluated with PVTCcannulated or ileo-rectal anastomised pigs fed diets containing two indigestible markers. Livest Prod Sci. 2000;62:133-41.

24. Kavanagh S, Lynch PB, O'Mara F, Caffrey PJ. A comparison of total collection and marker technique for the measurement of apparent digestibility of diets for growing pigs. Anim Feed Sci Technol. 2001;89:49-58.

25. Olukosi OA, Bolarinwa OA, Cowieson AJ, Adeola O. Marker type but not concentration influenced apparent ileal amino acid digestibility in phytasesupplemented diets for broiler chickens and pigs. J Anim Sci. 2012;90:4414-20.

26. Moore JH. Diurnal variations in the composition of the faeces of pigs on diets containing chromium oxide. Br J Nutr. 1957:11:273-88.

27. Horvath DJ, Peterson ME, Clawson AJ, Sheffy BE, Loosli JK. Diurnal variations in the composition of swine feces. J Anim Sci. 1958;17:869-74.

28. Ehle FR, Jeraci JL, Robertson JB, Van Soest PJ. The influence of dietary fiber on digestibility, rate of passage and gastrointestinal fermentation in pigs. J Anim Sci. 1982;55:1071-81.

29. Furuya S, Sakamoto K, Asano T, Takahashi S, Kameoka K. Effects of added dietary sodium polyacrylate on passage rate of markers and apparent digestibility by growing swine. J Anim Sci. 1978;47:159-65.

30. Pond WG, Pond KR, Ellis WC, Matis JH. Markers for estimating digesta flow in pigs and the effects of dietary fiber. J Anim Sci. 1986;63:1140-9.

31. Wilfart A, Montagne L, Simmins H, Noblet J, Van Milgen J. Digesta transit in different segments of the gastrointestinal tract of pigs as affected by insoluble fibre supplied by wheat bran. Br J Nutr. 2007:98:54-62.

\section{Submit your next manuscript to BioMed Central and we will help you at every step:}

- We accept pre-submission inquiries

- Our selector tool helps you to find the most relevant journal

- We provide round the clock customer support

- Convenient online submission

- Thorough peer review

- Inclusion in PubMed and all major indexing services

- Maximum visibility for your research

Submit your manuscript at www.biomedcentral.com/submit

) Biomed Central 